\title{
Urban Infill Development by Emphasizing Housing (Case Study: Sanandaj City)
}

\author{
Taher Parizadi \\ Department of Geography and Urban Planning, University of Isfahan, Isfahan, Iran \\ Tel: 91-2881-9280Ｅ-mail: tparizadi@yahoo.com \\ Hamid Reza Varesi \\ Department of Geography and Urban Planning, University of Isfahan, Isfahan, Iran \\ Tel: 98-31-1793-3160Ｅ-mail: varesi@ltr.ui.ac.ir
}

Asghar Zarabi

Department of Geography and Urban Planning, University of Isfahan, Isfahan, Iran

Tel: 98-31-1793-3160 E-mail: aszarrabi@yahoo.com

Received: December 30, 2011

Accepted: January 29, $2012 \quad$ Published: March 1, 2012

doi:10.5539/jsd.v5n3p112

URL: http://dx.doi.org/10.5539/jsd.v5n3p112

\begin{abstract}
Most cities in our country faced some problems such as physical disruption. These studies have been shown that the recent physical expansion of the city is because of the natural growth of the population, immigrations from villages and finally exceeding to farms and garden that located around the cities. In this research, we are looking for the most usable existing capabilities of Sanandaj by emphasizing on population structure and future needs to housing. The method research of this study is descriptive-analytic by using official data and urban development plan documents. In addition to applied methods for predicating the housing and population considering needs of housing in Sanandaj, population structure and the physical parameters of Sanandaj. Based on findings, infill lands and recycled lands of Sanandaj supporting all needs of housing services and horizontal development in mountainous cities with hard slope are unappealing for us.
\end{abstract}

Keywords: Housing, Urban infill development, Urban facilities and equipments, Population structure, Infill lands

\section{Introduction}

Housing is one of the most important needs of human life which accessing that is too complicated and difficult due to its characteristics. By considering technical developments in housing, changing circumstances of the society, increasing knowledge about human social, individual rights and the importance of supplying social needs of the society, housing issue has found new dimensions.

In our country, producing and supplying the houses are less than the demands because the growths of the population are far faster than the facilities of housing. Dust, we need a lot of lands with residential land use. Today, providing lands for housing is difficult special in metropolitan. At previous, need of housing was as shelter but today this has changed to a basic need for all household creating special forms in our lives. Since the third world countries have started a modernization process, their extended family patterns have changed to a nuclear pattern made most families to live in their own separate houses resulting small housing \& high-rise buildings. The kind and number of the household is a very important issue in housing planning.

Housing and its services especially in big cities are a challenge for urbanizing consultants to horizontal development in city that destroy the farms and also raises the price of urban facilities and utilities. Perhaps this policy (horizontal development) may be an solution to central and eastern cities, (of course for a short term), but in northern and western ones could be caused the physical disruption of the city due to geographical situation of cities. One of the cities that have a lot of problems at horizontal development is Sanandaj. Sanandaj has been 
surrounded between Abider Mountain in west and northern, eastern and southern the main part of the city has been situated on hills that it shows the importance of this research.

\section{Theoretical Principles}

Internal growth doesn't mean a neglect of the inner parts, vice versa the goal of it is creating discipline. Leading to a balanced and harmonious distribution of urban facilities and equipment, both inside and outside cities; an internal and external Balance, old and new, today and tomorrow adaptation (Habibi, 2005).

Several theories have been proposed about infill development. Such as:

- Development of infill lots and unstable buildings in developed areas are shown infill development (City parish planning commission, 2004).

- Infill development is economical using of vacant lands in urban developed areas. The locations that there are services and infrastructure like water, sewage system, access roads, and public transport services (Greensboro comprehensive plan, 2000).

- Infill development is residential done on the vacant lots that have reminded between buildings (Seifeddini, 2009).

- Infill development creating new buildings on vacant and unused lots of him neighboring centers and commercial areas. These places usually are located in our neighborhood which has infrastructure services such as access roads, water, electricity and etc. Infill development led to growth of life indicators in cities (Tarnay, 2004).

After several decades of migration to the suburbs of the city, many people have decided to return to the city, to use facilities and equipments. The negative aspects of living in the suburbs has strengthened this idea, such as traffic, wasting time and energy, economic costs and also far from work place and pleasure location from each other. So the idea of infill development has been formed there.

There for, is infill development more advantageous than other development? What are the advantages of infill development? We will answer to these questions despite all limitations of infill development, it has more advantageous than other development in our cities today.

\section{Research Method (Society and Space Research)}

The method of research is "descriptive - analytical", and data collection method is "documentery -field". The data are generally gathered from academic centre libraries like universities, organizations, institutes and research centers such as assistance and planning organization and internet, official statistics and censuses, urban development plans by consulting engineers, and so on. Statistic society is citizens and city of Sanandaj. At first by presentation of theoretical framework and by using models (potential function and regression); we have forecasted housing then trying to supply the housing needs and urban services in Sanandaj (Hekmat nia, 2007) (Figure 1).

\section{Research Materials}

Sanandaj is centre of Kurdistan province with 3688.6 acre area and has been located at west of Iran and south of Kurdistan province. Geographic coordinate system is 14degree, 35 northern latitude and 46-degree eastern longitude. And the height of sea surface is between 1450 to 1538 meters in different parts of the city (Habibi, 2008).

Sanandaj has been surrounded between Mountains such as: Abidar, Koochkeh rashTtoosnozar. So the growth of city has been limited from in south-west and north - east. Many parts of Sanandaj have been located on hills. Topological situation of city and the mountains have been caused the city to be surrounded in a flat valley. Also form of networks and streets are according to slop of the land and the forms of some parts of city are as stairs and terrace level. Many alleys are narrow and tortuous except new neighborhoods. Gheshlagh River with 95 kilometers long is passes through three kilometers east of Sanandaj.

Today volume of river water has decreased dramatically due to lack of rain and snow and physical expansion of the city. The mountains that have surrounded around Sanandaj are Abider, Koochsar, Sheikh Maroof, Masjed mirza, Mlakavoo, Charkhlan, and Serajeddin. Sanandaj 512 kilometers is far from Tehran. Also Sanandaj is $140 \mathrm{Km}$ far from the borderline in Marivan (http://www.sanandaj.gov.ir) (Figure 2). 


\section{Discussion and Findings}

\subsection{Foreseeing of Population}

Before any planning should be considered important items such as population. In this research has been estimated population of Sanandaj to 2022 by liner regression and exponential function model (Table 1) (Figure $3)$.

\subsection{Estimations Based on Needs}

Estimates based on needs method will be considered housing needs in year without consideration income or job. It generally attends to population parameters and existing houses. At first, in this method, the number of households is compared with the number of houses, and according to one specific standard is estimated the lake of houses. Then by using rate of population growth and adding old, unsafe houses, we can calculate the number of the houses that we need in future. This method is divided to two methods: raw and general. Raw method is used when the needed information is not achieved (poor Mohammad, 2005).

\subsubsection{Raw Method}

When the statistics are not enough to estimation, this method is used to estimate approximately for housing needs .In most of the countries the total population, the rate o growth and households size is clear. Also there is total number of existing and acceptable houses the formula of this method is:

$$
\mathbf{E}(\mathbf{T})=\mathbf{H}-\mathbf{U}+\mathbf{H}(\mathbf{t})+\mathbf{r} \mathbf{u}(\mathbf{t})
$$

Estimating of need housing area:

\section{The number of the household* Optimal area per household $5761300=100 * 57613$}

According to the needed number of housing units based on raw method in housing planning of Sanandaj and the optimal area per household $\left(100 \mathrm{~m}^{2}\right)$, the need of housing in Sanandaj to 1400 is 576 acre (Table 2).

\subsubsection{General Method}

In this method, we must consider all effective features that affecting on housing, such as: Current housing conditions, population changes and general policies. The formula of this method is:

$$
E(t)=k(E 1+E 2+E 3+E 4+E 6(t))+E 5+E 7(t)
$$

Estimating of need housing area:

\section{The number of the household* Optimal area per household $6440900=100 * 64409$}

According to the need of housing units based on general method in housing planning of Sanandaj according to the optimal area per household $\left(100 \mathrm{~m}^{2}\right)$, the need of housing in Sanandaj to 2022 is 644 acre.

There are 1578 acre vacant lots in Sanandaj (comprehensive plan of Sanandaj, 2008) by considering the average density in Sanandaj that is $180 \%$ (means three floors on garage pilot), we can use infill lands more than our needs in this city (Table 3 ).

\subsubsection{Emphasize on Population Structure}

The important object about population is structure of the population, such as: household size and household number. According to the definitions a household has been consisted of 2 or more persons that living in the same house or person who lives alone and supplies his own needs (Poor Mohammadi, 2004). Due to the definition of household $\mathrm{n}$, the number of household is more effective than the number of population (Reza Zadeh, 2009). According to Table (3), we can understand the population of 15-64 year olds in Sanandaj has been increased in 1987-2007. This group is going to start the activities and get married. so they need physical space. According to table (4) the household size has been decreased in 1987-2007 so the number of household increase and we need housing units. According to the population of age groups, the most of population are between 20-24 age group, so it shows that Sanandaj population is young and it will need houses now and future (Figure 4).

\section{Foreseeing the Number of Needed Housing Units Based on Ratified Comprehensive Plan Theories}

According to comprehensive plan in our cities of country, $15 \%$ to $20 \%$ lands are vacant. Cities that grow more than other cities have more vacant lands due to urban development. Sometimes unstable lands or recyclable lands in large cities may be reminded for us as ruins, natural disasters or unsafe; but in fact they are another chances to urban infill development and economical boom in neighborhood at city. 
By considering of Sanandaj comprehensive plan we understand that Sanandaj have 1578 acre inside the city as left alone, brown or uncultivated lands, that they are more than $48 / 9 \mathrm{~m}^{2}$ and their area are more than $41 \%$ of the city.

Sanandaj lakes in many public land uses. Now the area of Sanandaj (in 1383) is 3815 acre and $118 / 3 \mathrm{~m}^{2}$ per capita. At first it sound that per capita of urban lands is balanced but in fact about $48 / 9 \mathrm{~m}^{2}$ per capita of urban lands are vacant and unstable, the real per capita of urban lands is $69 / 3 \mathrm{~m}^{2}$. So per capita of public land uses are less than the standards. In during 10 years of development plan should be increased per capita of urban land uses and should be balanced other public land uses. So it is better that we start the infill development to increase the densities.

According to comprehensive plan of Sanandaj in 2016 the population of the city will be 392900 , so the area of city will be 4066, thus will be added 250 acre (Table 6).

According to the comprehensive plan studies in Sanandaj, the population in 1394 will be 392900; this means at the end of the period, 70450 person would be added to the population. Due to the households size of Sanandaj in the last year is decreased to $4 / 5$ person, so in 1394 Sanandaj will have 8731 residential households. Therefore, it predicated that in during of plan would be added about 16598 households in city. Based on co efficiency of 1/05 household in per unit, we will need 15807 housing units; in addition to the present shortage of housing units, this would be more than 22573 units. Per capita of residential land use are $21 / 5 \mathrm{~m}^{2}$. This will be increased during development plan to $30 \mathrm{~m}^{2}$. According to this per capita, the acreage of the residential land use would be 1178 acre at the end of the period, so we will need 483 acre in future.

\section{Studying the Need for Facilities and Equipments in Sanandaj}

One of the important issues of infill development projects is urban infrastructure facilities and equipment. So researchers have used from information of "Tadbir - shahr" consulting engineers. Their results are:

\subsection{Water}

According to water office of Kurdistan province the amount of underground water and surface water (gheshlagh dam) are 118/5 million $\mathrm{m}^{3}$ annually. So we will not water problem by comparing the water need at end of plan (254 liter) and recoverable water.

\subsection{Urban Water Facilities}

At the moment one purification plant purify water for 300000 people (1057 lit/s) in Sanandaj, the second one is built at soon.

\subsection{Sewage}

According to information of "Sewage - Water" Company, $95 \%$ of area comprehensive plan is covered by sewage network also physical progress of construction of the purification plant is $70 \%$ in Sanandaj. In urban centers and the middle parts, the sewage system is very traditional which the most of the houses are not connected to the main channel yet.

\subsection{Electricity}

According to electrical power of Kurdistan province at the end of plan there isn't problem about it.

\subsection{Gas}

Sanandaj is a green city (has been used gas as fuel) the needed gas at the end of plan for 500000 people is 1790 million $\mathrm{m}^{3}$ so there isn't problems about it.

\subsection{Telecommunication}

According to telecommunication information, the capacity of the current telecommunication is enough as cable network and phone line for a long time.

\subsection{Urban Equipments}

Urban equipments are suitable situation in Sanandaj. This is due to a balanced distribution of the equipments in the city. Of course the graveyards inside the city should change to green areas, slaughterhouse must be moved (due to ecological problems), and the number of fire stations and gas stations must be increased (comprehensive plan of Sanandaj, 2008). 


\section{Conclusion}

According to this study, we find out that there are many capabilities in the neighborhood that could be used in the best ways. Instead, urban planners pay attention to horizontal developments. While there is a lack of space to build, they use lands that have been located around the city with no consideration to the functions or tense of the activities or density of its. As we can see in the comprehensive plan, more than 1578 acre of Sanandaj are vacant that should be used urban planning in future.

In housing planning, should be paid enough attention to the changes of population also considering population structure. The changes of population structure are very effective on the housing and number of housing units.

Generally the results of this study show that if planning of housing is just based on population changes, foreseeing of housing is true. Just in normal situations that the population structure has not changed any special changes, estimating the housing needs is acceptable.

The raw method for estimating the housing needs are used to calculate the housing needs per capita levels and housing densities, but in special situations that the population has been changed their structure (due to economic and the society condition) we must use more complicated methods to foresee themes.

This study shows that housing in special position such as changes of population is affected more than changes of population structure. For example young person in population, due to Iran have experienced special changes of population at the first years of the Islamic revolution, so its necessary all of urban plans pay attention to population structure and number of new households for considering needed housing.

For providing the needed housing in Sanandaj is presented three strategies:

a) By developing infill lands inside the city (with supplying per capita residential land use) should be answer to new households.

b) By building small housing that it must be answered to the needed housing units at the end of plan with the same as housing density and residential land use .

c) Increasing the housing density that it supports needed area residential and other needed services for accommodation of populations.

\section{References}

City-parish planning Commission. (2004). Information Bulletin Number, April.

Elkin, t. et al. (1991). Receiving the City: Towards Sustainable Urban Development, Friends Earth, London.

Fakhr Ahmad, S. M. (2006). Future of urban development planning by emphasizing determined infill vacant land use (case study: Do Gonbadan): Msc thesis, Tarbiyat Modare university.

Fariss, J. Terrence. (2001). The Barrier to using urban infill development to achieve Smart growth. Housing policy debate, 12,1 .

Greensboro comprehensive plan steering committee. (2000). Infill development for Greensboro, NC (A white Paper).

Hafez nia, M. R. (2009). An introduction to the research method in humanities. (14th ed.). Tehran: Samt.

Hafez nia, M. R. (2009). An introduction to the research method in humanities. (14th ed.). Tehran: Samt.

Habibi, K., \& Ahmad Poor, A. (2006). Physical-spatial development of Sanandaj by using GIS. Kurdistan: University Publications of Kurdistan.

Habibi, S. M. (2002). Studying of physical-spatial development of Sanandaj by using GIS, PhD thesis in Geography and urban planning, Tehran University.

Hekmat nia, H., \& Moosavi, M. (2007). Model application in geography with emphasis on urban and regional planning. Yazd: Elme Novin publication.

Heidari, M. (2007). Analyses of physical development planning in Koohdasht, master thesis, Esfahan, Esfahan University.

Iran census centre. (2007). The results of census of people and housing 1967-2007.

Lucas, Barbar. (2005). Infill development- an efficient use of resources, Washtenaw County planning and environment, solid waste programs.

Negar pars consulting engineers. (2007). Improvement and empowerment plan of the population in Sanandaj, 
first and second volume.

Poor Mohammadi, M. R. (2004). Housing planning. (2rd ed.). Tehran: Samt.

Reza Zade, R. (2009). Study the housing needs by emphasizing changes population structure in Tehran. International Journal of Engineering Science and Technology.

Saraee, M. H. (2001). Land process and its affect on developing model of the cities (case study Yazd), $\mathrm{PhD}$ thesis, Esfahan University.

Sharifi fard, H. (1999). Geographical analyses on housing development in Ahvaz, Msc thesis, Esfahan, Esfahan University.

Statistics of Kurdistan province. (2009). Planning Department Governor of Kurdistan, Sanandaj, Kurdistan province.

Tadbire-Shahre Andishe consultant engineers. (2007). Comprehensive and developed plan of Sanandaj, Department of Housing and Urban.

www.udro.org.ir

www.dolat.ir

Zangi abadi, A. (1991). Spatial analyses of physical development pattern in Kerman, Master thesis, Tehran, Tarbiyat Modare University.

Table 1. Foreseeing of Sanandaj population to 1400

\begin{tabular}{|c|c|c|c|}
\hline $\begin{array}{c}\text { foreseeing of Sanandaj population by using exponential } \\
\text { function model }\end{array}$ & \multicolumn{2}{c|}{$\begin{array}{c}\text { foreseeing of Sanandaj population by using } \\
\text { regression method liner }\end{array}$} \\
\hline population & year & population & year \\
\hline 277808 & 1375 & 54578 & 1345 \\
\hline 316832 & 1385 & 95872 & 1355 \\
\hline 349808 & 1390 & 204537 & 1365 \\
\hline 386216 & 1395 & 277808 & 1375 \\
\hline 426413 & 1400 & 316832 & 1385 \\
\hline & & 366536 & 1390 \\
\hline & & 401858 & 1395 \\
\hline & & 437180 & 1400 \\
\hline
\end{tabular}

Source: Authors' calculations

Table 2. Estimated housing units needed in Sanandaj with raw model to 2022

\begin{tabular}{|c|c|c|}
\hline Number & Name & Variant \\
\hline 57613 & the number of needed houses up to $\mathrm{t}$ & $\mathrm{ET}$ \\
\hline 81473 & The number of household available & $\mathrm{H}$ \\
\hline 60570 & The number of housing units available & $\mathrm{U}$ \\
\hline 30660 & The number of new households & $\mathrm{H}(\mathrm{t})$ \\
\hline 6050 & Percent of housing units that will need To destruction and reconstruction time $\mathrm{t}(10 \%)$ & $\mathrm{Ru}(\mathrm{t})$ \\
\hline
\end{tabular}

Source: Census of people and housing (1967-2007) Authors' calculations 
Table 3. Estimated housing units needed in Sanandaj with general model to 2022

\begin{tabular}{|c|c|c|}
\hline Number & Name & Variant \\
\hline 64409 & the number of needed houses up to $(\mathrm{t})$ & $\mathrm{ET}$ \\
\hline $5 \%$ & Coefficient of empty homes & $\mathrm{k}$ \\
\hline 20903 & the current lack of housing & E1 \\
\hline 12114 & under standard housing units & E2 \\
\hline 30624 & the need of housing for each household & E3 \\
\hline 0 & the need based on deleting or decreasing the density & E4 \\
\hline 30660$)$ & the need based on population growth in $(\mathrm{t})$ & E6(t) \\
\hline 6050 & Housing units that should be destroyed & E5 \\
\hline 11209 & Housing units that should be destroyed in during of planning & E7(t) \\
\hline
\end{tabular}

Source: Census of people and housing (1967-2007)

Table 4. The percentage of population in main age groups in Sanandaj and country (1987-2007)

\begin{tabular}{|c|c|c|c|c|}
\hline Population growth & Household size & Population & Household & Year \\
\hline Population growth & Household size & Population & household & year \\
\hline- & 5.02 & 204537 & 40752 & 1987 \\
\hline 3.59 & 5.04 & 244039 & 48366 & 1992 \\
\hline 2.6 & 4.68 & 277808 & 59357 & 1997 \\
\hline 1.3 & 3.9 & 316832 & 81473 & 2007 \\
\hline
\end{tabular}

Source: Iran census center

Table 5. Changes of population, household and the household size in Sanandaj during 1987-2007

\begin{tabular}{|c|c|c|c|c|c|c|}
\hline \multicolumn{2}{|c|}{2007} & \multicolumn{2}{c|}{1997} & \multicolumn{2}{c|}{1987} & $\begin{array}{c}\text { The main age } \\
\text { groups }\end{array}$ \\
\hline Sanandaj & country & Sanandaj & country & Sanandaj & country & $0-14$ \\
\hline 21.6 & 25.08 & 38.5 & 39.5 & 43.2 & 45.5 & $15-64$ \\
\hline 73 & 69.73 & 58.8 & 56.1 & 50.7 & 51.5 & 65 \\
\hline 4.9 & 5.18 & 3.7 & 4.3 & 6 & 3 & 65 \\
\hline
\end{tabular}

Source: the statistics of Kurdistan province

Table 6. The area of public land use in Sanandaj in present situation and forecasts to 2016

\begin{tabular}{|c|c|c|c|c|c|c|}
\hline \multicolumn{2}{|c|}{ Changes } & \multicolumn{2}{|c|}{ Suggested (2016) } & \multicolumn{2}{|c|}{ Now (2005) } & \multirow[b]{2}{*}{ Main landuse } \\
\hline $\begin{array}{l}\text { per capita } \\
\left(\mathrm{m}^{2}\right)\end{array}$ & $\begin{array}{l}\text { Area } \\
\text { (acre) }\end{array}$ & $\begin{array}{l}\text { per capita } \\
\left(\mathrm{m}^{2}\right)\end{array}$ & $\begin{array}{l}\text { Area } \\
\text { (acre) }\end{array}$ & $\begin{array}{c}\text { per capita } \\
\left(\mathrm{m}^{2}\right)\end{array}$ & Area (acre) & \\
\hline 8.43 & 483 & 30 & 1178 & 21.57 & 695 & residential \\
\hline 23.91 & 1235 & 66.14 & 2600 & 42.23 & 1365 & Public services \\
\hline- & $1578-$ & - & - & 48.95 & 1578 & Vacant lands \\
\hline $0.53-$ & $17-$ & - & - & 0.53 & 17 & graveyards inside the city \\
\hline $1.05-$ & $34-$ & - & - & 1.05 & 34 & lands military \\
\hline $0.44-$ & 0.4 & 2.13 & 83.5 & 2.57 & 83 & Gardens and farms \\
\hline 4.3 & 172 & 4.78 & 187.9 & 0.48 & 15 & green areas \\
\hline $0.52-$ & $14-$ & 0.38 & 14.9 & 0.9 & 28 & industry and work shop \\
\hline 34 & 249 & 1.3 .43 & 4065 & 69.33 & 3815 & urban area \\
\hline
\end{tabular}

Source: the reports of Sanandaj comprehensive plan (2008)

Per capita of infill lands hasn't been collected with others per capita 


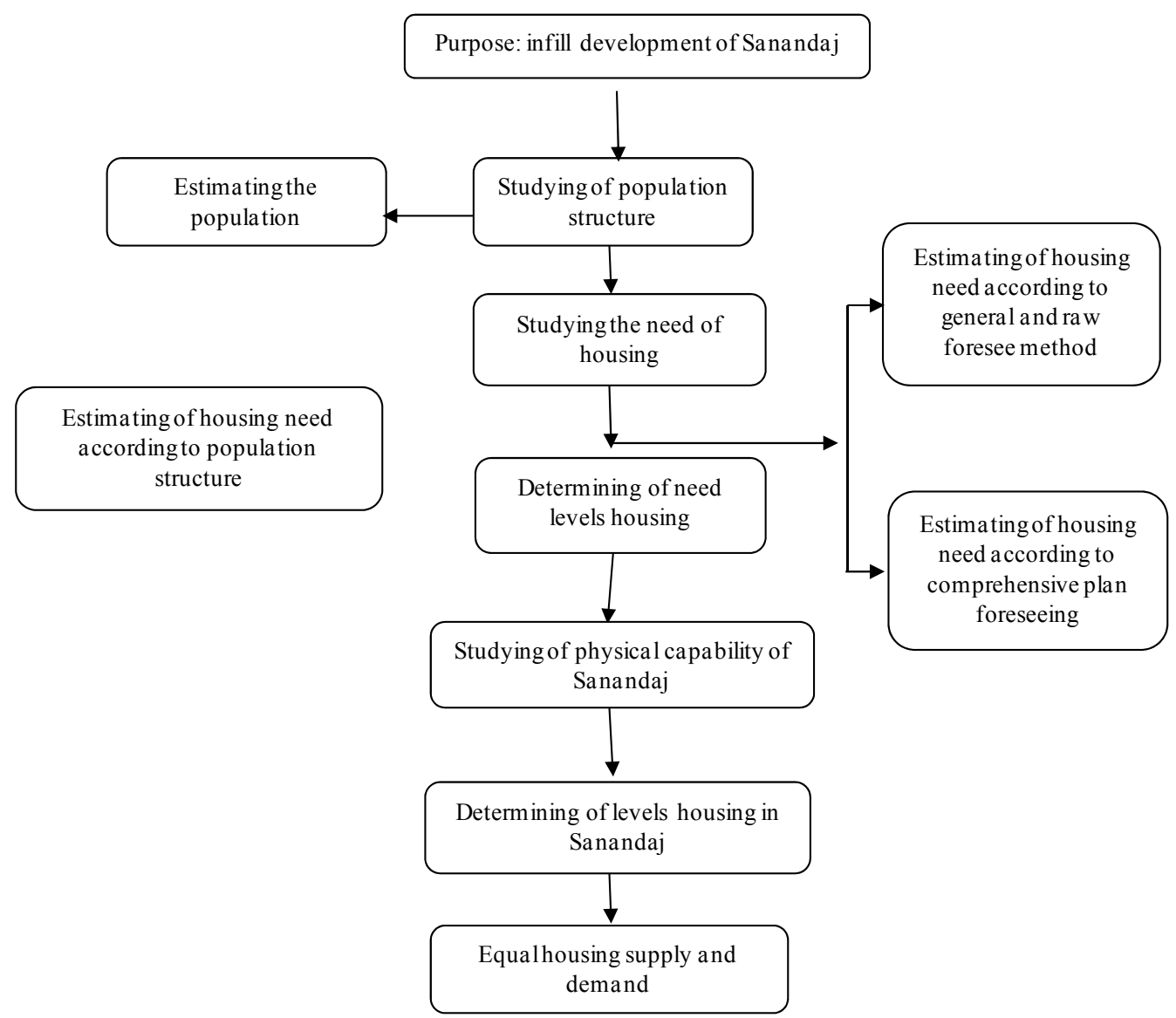

Figure 1. Conceptual model of the study

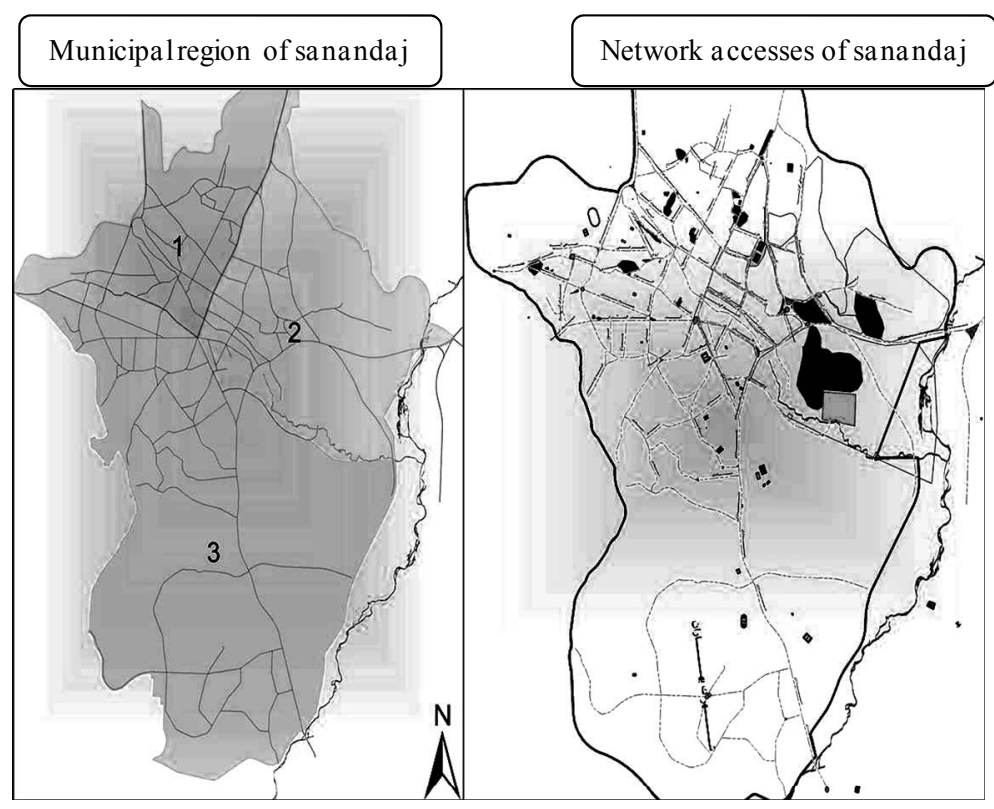

Figure 2. The plan of network and municipal regions of Sanandaj

Source: municipality of Sanandaj web-side 


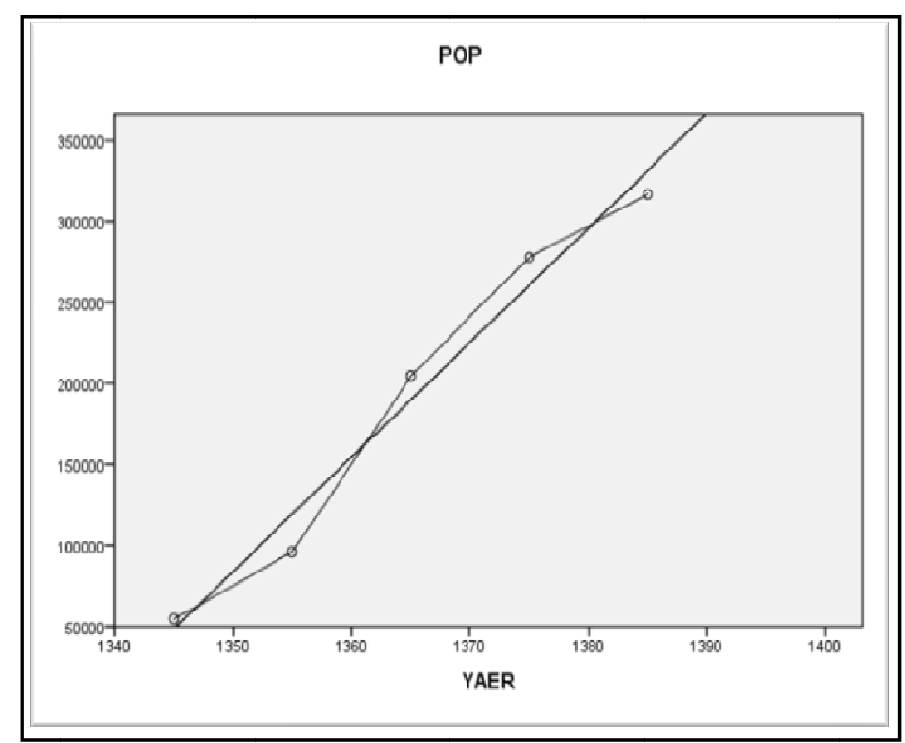

Figure 3. Graphic view of linear regression equation of Sanandaj population Source: Authors' calculations

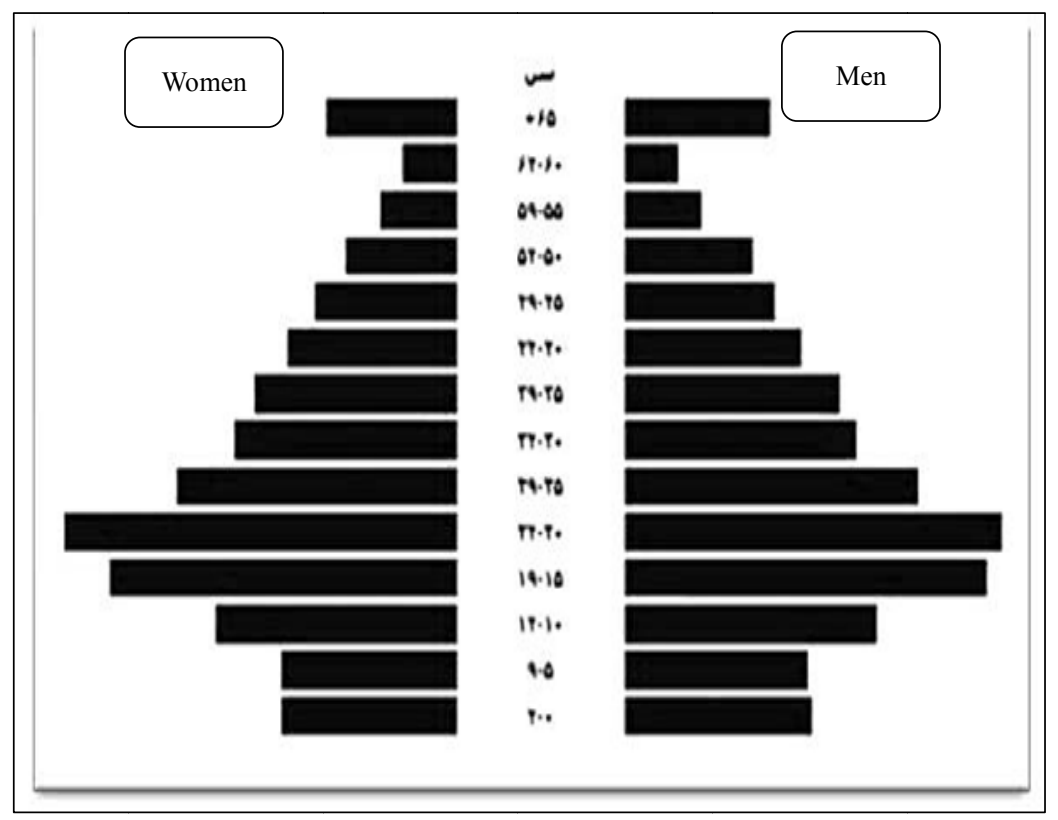

Figure 4. Sanandaj Age - gender pyramid 1987-2007

Source: Census of people and housing (2006-2007) Authors' calculations 